UDC 621.397.33

A.V. Sadchenko, PhD, Assoc.Prof., O.A. Kushnirenko,

A.V. Troyansky, $\mathrm{PhD}$, Assoc.Prof.

Odessa National Polytechnic University, 1 Shevchenko Ave., 65044 Odessa, Ukraine; e-mail: troy_shur@mail.ru

\title{
THE ALGORITHM OF RANDOM LENGTH SEQUENCES SYNTHESIS FOR FRAME SYNCHRONIZATION OF DIGITAL TELEVISION SYSTEMS
}

А.В. Садченко, О.А. Кушніренко, О.В. Троянський. Алгоритм синтезу послідовностей довільної довжини для кадрової синхронізації систем цифрового телебачення. У системах цифрового телебачення потрібно забезпечити виконання всіх операцій 3 обробки цифрових сигналів синхронно і послідовно. Кадрова синхронізація викликана необхідністю узгодження по фазі передавача і приймача таким чином, щоб можна було ідентифікувати початок кадру. Сигналами кадрової синхронізації часто використовуються бінарні послідовності великої довжини з хорошими неперіодичними автокореляційними функціями. Мета: Розробці алгоритму синтезу таких послідовностей довільної довжини присвячено дану роботу. Матеріали і методи: У роботі проведено порівняльний аналіз відомих послідовностей, які можуть використовуватися як синхронізуючі, виявлено їх переваги і недоліки. Запропоновано алгоритм синтезу бінарних синхронізуючих послідовностей довільної довжини з хорошими автокореляційними властивостями на базі генератора шуму з рівномірним законом розподілу ймовірності. Вихідним матеріалом для синтезу бінарних послідовностей із заданими властивостями запропоновано використовувати напівпровідниковий генератор «білого» шуму. Результати: Проведено статистичний аналіз вихідних реалізацій «білого» шуму і синтезованих послідовностей для кадрової синхронізації систем цифрового телебачення. Проведено порівняльний аналіз синтезованих послідовностей з відомими. Результати аналізу показують переваги отриманих послідовностей в порівнянні з відомими. Проведене моделювання підтверджує отримані результати. Висновки: Таким чином, отримано алгоритм пошуку бінарних синхронізуючих послідовностей із заданими автокореляційними властивостями, відповідно до якого може бути отримано послідовності, що перевершують відомі і не мають обмежень по довжині. Отримані синхронізуючі послідовності можуть бути використані для кадрової синхронізації в сучасних цифрових системах передачі інформації, що підвищить їх ефективність і завадостійкість.

Ключові слова: кадрова синхронізація, бінарні синхронізуючі послідовності, «білий» шум, автокореляційна функція.

A.V. Sadchenko, O.A. Kushnirenko, A.V. Troyansky. The algorithm of random length sequences synthesis for frame synchronization of digital television systems. Digital television systems need to ensure that all digital signals processing operations are performed simultaneously and consistently. Frame synchronization dictated by the need to match phases of transmitter and receiver so that it would be possible to identify the start of a frame. As a frame synchronization signals are often used long length binary sequence with good aperiodic autocorrelation function. Aim: This work is dedicated to the development of the algorithm of random length sequences synthesis. Materials and Methods: The paper provides a comparative analysis of the known sequences, which can be used at present as synchronization ones, revealed their advantages and disadvantages. This work proposes the algorithm for the synthesis of binary synchronization sequences of random length with good autocorrelation properties based on noise generator with a uniform distribution law of probabilities. A "white noise" semiconductor generator is proposed to use as the initial material for the synthesis of binary sequences with desired properties. Results: The statistical analysis of the initial implementations of the "white noise" and synthesized sequences for frame synchronization of digital television is conducted. The comparative analysis of the synthesized sequences with known ones was carried out. The results show the benefits of obtained sequences in compare with known ones. The performed simulations confirm the obtained results. Conclusions: Thus, the search algorithm of binary synchronization sequences with desired autocorrelation properties received. According to this algorithm, the sequence can be longer in length and without length limitations. The received sync sequence can be used for frame synchronization in modern digital communication systems that will increase their efficiency and noise immunity.

Keywords: frame synchronization, synchronization binary sequence, white noise, autocorrelation function.

Introduction. The digital television systems, currently widespread practiced throughout the world, represent a particular aspect of digital communication systems. At such systems need to ensure that all digital signals processing operations are performed simultaneously and consistently [1].

The data transmission frame format in a digital color television is shown at Fig. 1, where each channel has its own personal address. The frame size, in most cases, is selected as power of 2. 


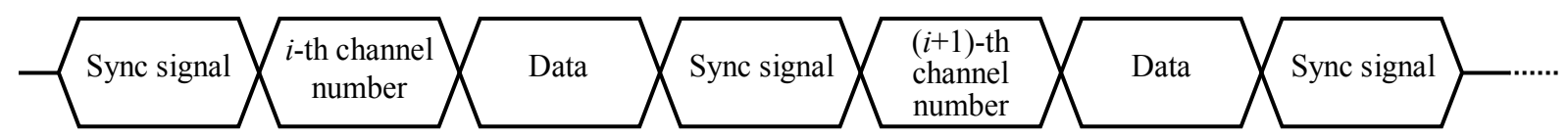

Fig. 1. Data transmission frame format at digital color television systems

Frame synchronization dictated by the need to match phases of transmitter and receiver so that it would be possible to identify the start of a frame. As a frame synchronization signals are often used long length binary sequence with good aperiodic autocorrelation function [2].

Thus, this work is dedicated to the development of the algorithm of random length sequences synthesis.

For synchronization signal extracting at the receiving side required is the reference sequence containing correlation device or a matched filter [3]. The frame synchronization block diagram is shown at Fig. 2. The synchronization is carried out due to data accumulation. Supposingly, at the start of each frame data pack a special signal will be transferred and identified by the matched filter. The threshold device checked, sync pulses, with the aim to reduce the false triggering probability are fed to a multioutput delay line, from which outputs the signal is sent to the multi-input circuit "AND". If at least one input of the "AND" circuit the signal will be missing, it will also be absent at the output. A stable generator produces a sequence of short rectangular pulses under frames rate. When the sync signal arrives at the input of stable sync pulses generator there occurs the binding in phase with the input signal [4].

Since the convolution calculation takes place after demodulation, the errors appear in the form of changes in the values of the signal's individual positions, i.e. change for the opposite values. As a model of the communication channel, we shall consider a binary symmetric channel where the transitions of symbol " -1 " into the "+1" symbol and the symbol "+1" into the symbol " -1 " are equiprobable.

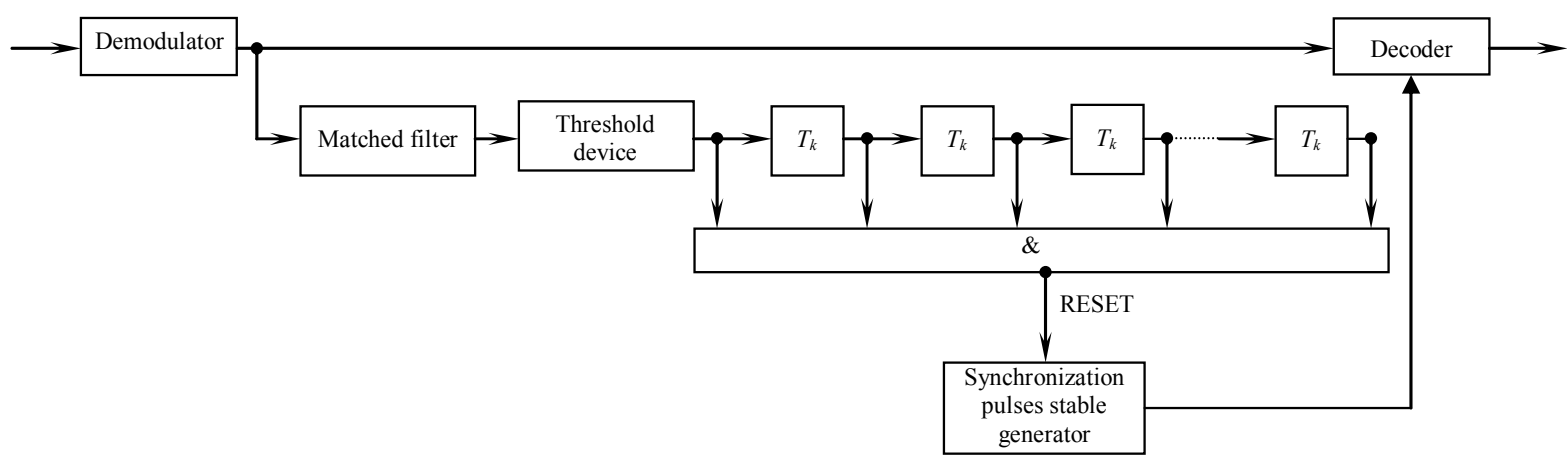

Fig. 2. Structural diagram of frame synchronization: $T_{\kappa}$ - line of one time step delay

Obviously, the synchronization sequence should have a low sidelobe level (SLL) of correlation function that being defined as

$$
R(k)=\frac{1}{m} \sum_{i=0}^{m} c(i) c(i+k), k=\overline{0, m} .
$$

For synchronization sequences we can use Barker codes, maximum length sequence or an Msequence, Gold codes [2].

The best correlation properties are attributed to Barker codes, but only nine Barker sequences are known, all of length $N$ at most 13 (Barker codes do exist only for lengths 4, 5, 7, 11, 13). M-sequences and Gold codes exist only for odd lengths divisible to $N=2^{k}-1, k=2,3,4, \ldots$ 
In this regard, the synchronization signal building we face the problem of synthesizing video sequences of arbitrary length (e.g., non-standard codes with a length of 8, 16, 32, 64 elements). The easiest way to get the synchronization sequence length of $N=2^{k}, k=2,3,4, \ldots$ is to complete the Msequence for reaching an even number.

Considering M-sequence of $N=7$ length (Fig. 3) which coincides with a Barker code: the autocorrelation function (ACF) for Barker code of $N=7$ length is shown in Fig. 4, $a$. After completing the sequence by adding first symbol " -1 " the ACF takes the form shown in Fig. 4, $b$.

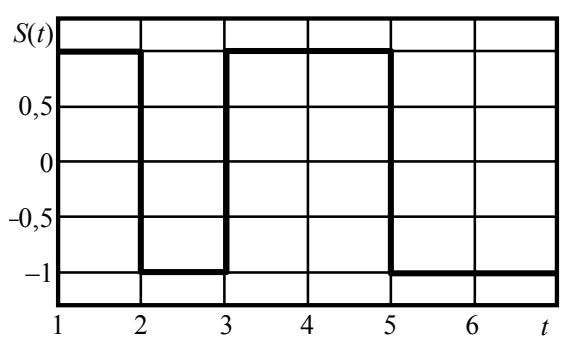

Fig.3. Envelope of the Barker sequence of $N=7$ length
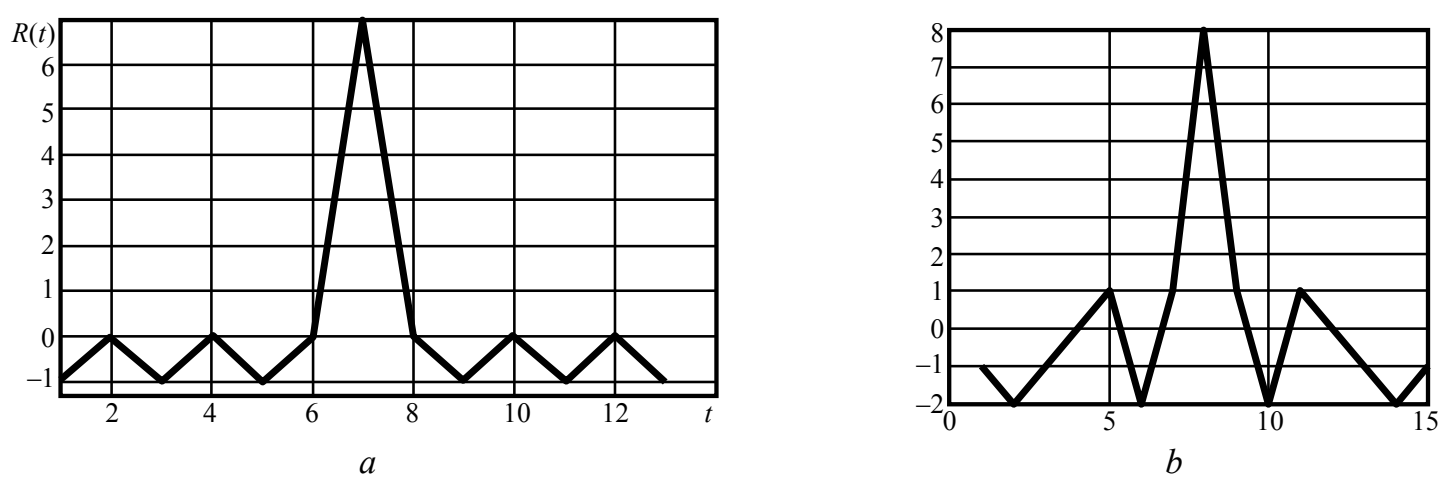

Fig. 4. ACF for Barker code of $N=7$ length and additional code of $N=8(-1)$ length

It is clear that the "augmented" sequence's correlation properties deterioration will be the greater, the more elements completed.

The aim of research is to development of the search algorithm of binary synchronization sequences with predefined autocorrelation properties, and comparative analysis of the synthesized sequences with known.

Materials and Methods. To find the binary sequences with desired properties of lengths $N<40$ we can use the exhaustive search algorithm. However, for large values of $N$, the search time is unacceptable increasing.

Well-known [2], that signal having an autocorrelation function that is close to the ideal, i.e. with low sidelobe level, should have a broad spectrum approximated to the spectrum of white noise. Therefore, for the noise-like binary sequences of $N>40$ length proposed is to use a correlation algorithm for analyzing the white noise segments of $N$ samples length, quantized for the levels $-1,1$.

Variate transformation should be implemented according to the following rule:

$$
\xi_{\text {out }}=\left\{\begin{array}{l}
1, \xi_{\text {in }} \geq \frac{\Delta \xi}{2} \\
-1, \xi_{\text {in }}<\frac{\Delta \xi}{2}
\end{array},\right.
$$

where $\Delta \xi-$ initial spectrum of random value changes. 
The source noise can be obtained algorithmically using, for example, a congruential generator, or physically, using a semiconductor noise generator.

A noise generating circuit quantized to two levels based on semiconductor noise generator is shown at Fig. 5.

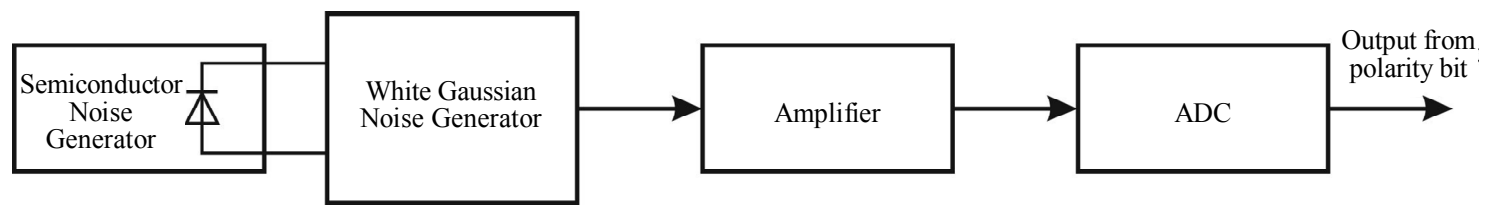

Fig. 5. Semiconductor noise generator

Analysis of the noise implementations' statistical characteristics carried out in Scilab environment, showed a good agreement between the obtained distribution law and the uniform distribution law. The initial data used at the statistical characteristics' analysis represented the noise under three implementation types, the number of samples for each implementation $n=10000$.

To search for signals with given LSL of ACF applicable is the following algorithm:

Step 1. Setting the sequence length $N$ and the required LSL $R_{b}$. The iterations number is $M$.

Step 2. Saving the file with noise sequence of length $N$.

Step 3. ACF calculation.

Step 4. Maximum SLL calculation $R_{b \max }=\max _{k}|R(k)|, k=\overline{1, m}$.

Step 5. Checking the condition $R_{b \max } \leq R_{b}$. If not fulfilled, and the iterations number is not reached, go back to Step 2. If condition is satisfied, go to Step 6.

Step 6. Saving the found sequence.

Results. The comparative characteristics for code sequences, constructed using various algorithms (exhaustive search, "noisy" search) are given at Table 1.

Table 1

Sidelobe level of autocorrelation function for code sequences obtained by different methods

\begin{tabular}{c|c|c|c|c|c|c|c|c|c|c|c|c|c|c}
\hline Code length & $\mathbf{4}$ & $\mathbf{5}$ & $\mathbf{6}$ & $\mathbf{7}$ & $\mathbf{8}$ & $\mathbf{9}$ & $\mathbf{1 0}$ & $\mathbf{1 1}$ & $\mathbf{1 2}$ & $\mathbf{1 3}$ & $\mathbf{1 4}$ & $\mathbf{1 5}$ & $\mathbf{1 6}$ & $\mathbf{1 7}$ \\
\hline $\begin{array}{c}\text { M-sequence } \\
\begin{array}{c}\text { Exhaustive } \\
\text { search }\end{array}\end{array}$ & 1 & 1 & 2 & 1 & 3 & 3 & 2 & 1 & 2 & 1 & 2 & 2 & 2 & 3 \\
\hline "Noisy" search & 1 & 1 & 2 & 1 & 3 & 3 & 2 & 1 & 2 & 1 & 2 & 2 & 2 & 3 \\
\hline Code length & $\mathbf{1 8}$ & $\mathbf{1 9}$ & $\mathbf{2 0}$ & $\mathbf{2 1}$ & $\mathbf{2 2}$ & $\mathbf{2 3}$ & $\mathbf{2 4}$ & $\mathbf{2 5}$ & $\mathbf{2 6}$ & $\mathbf{2 7}$ & $\mathbf{2 8}$ & $\mathbf{2 9}$ & $\mathbf{3 0}$ & $\mathbf{3 1}$ \\
\hline M-sequence & & & & & & & & & & & & & & 4 \\
\hline $\begin{array}{c}\text { Exhaustive } \\
\text { search }\end{array}$ & 2 & 3 & 3 & 2 & 3 & 3 & 3 & 3 & 3 & 3 & 3 & 3 & 3 & 3 \\
\hline "Noisy" search & 2 & 3 & 3 & 2 & 3 & 3 & 3 & 3 & 3 & 3 & 3 & 3 & 3 & 3 \\
\hline Code length & $\mathbf{3 2}$ & $\mathbf{3 3}$ & $\mathbf{3 4}$ & $\mathbf{3 5}$ & $\mathbf{3 6}$ & $\mathbf{3 7}$ & $\mathbf{3 8}$ & $\mathbf{3 9}$ & $\mathbf{4 0}$ & $\mathbf{4 1}$ & $\mathbf{4 2}$ & $\mathbf{3 4}$ & $\mathbf{4 4}$ & $\mathbf{4 5}$ \\
\hline M-sequence & & & & & & & & & & & & & & \\
\hline $\begin{array}{c}\text { Exhaustive } \\
\text { search }\end{array}$ & 3 & 4 & 4 & 4 & 4 & 4 & 4 & 4 & 5 & 5 & 5 & 5 & 5 & 5 \\
\hline "Noisy" search & 3 & 4 & 4 & 4 & 4 & 4 & 4 & 4 & 5 & 5 & 5 & 5 & 5 & 5 \\
\hline Code length & $\mathbf{4 6}$ & $\mathbf{4 7}$ & $\mathbf{4 8}$ & $\mathbf{4 9}$ & $\mathbf{5 0}$ & $\mathbf{5 1}$ & $\mathbf{5 2}$ & $\mathbf{5 3}$ & $\mathbf{5 4}$ & $\mathbf{5 5}$ & $\mathbf{5 6}$ & $\mathbf{5 7}$ & $\mathbf{5 8}$ & $\mathbf{5 9}$ \\
\hline M-sequence & & & & & & & & & & & & & & \\
\hline $\begin{array}{c}\text { Exhaustive } \\
\text { search }\end{array}$ & 6 & 6 & 6 & 6 & 6 & 6 & 6 & 6 & 6 & 6 & 6 & 6 & 6 & 6 \\
\hline "Noisy" search & 6 & 6 & 6 & 6 & 6 & 6 & 6 & 6 & 6 & 6 & 6 & 6 & 6 & 6 \\
\hline
\end{tabular}

Examples of autocorrelation signals for some lengths, found using the white noise areas correlation analysis method are given at Table 2. 
Analysis of the data represented at Table 1 shows that the results obtained by the exhaustive search method, and by the "noisy" search have similar levels of ACF sidelobes $R_{b \text { max }}$ overpassing by this indicator the M-sequences. Furthermore, these methods provide getting a sequence of any length.

Essential to note is that the search of binary sequences with desired autocorrelation properties for $N>40$ values by exhaustive method leads to an unacceptable increase in search time. This shortage is absent at the proposed method of "noisy" search.

Table 2

Examples of the obtained sequences' $A C F$

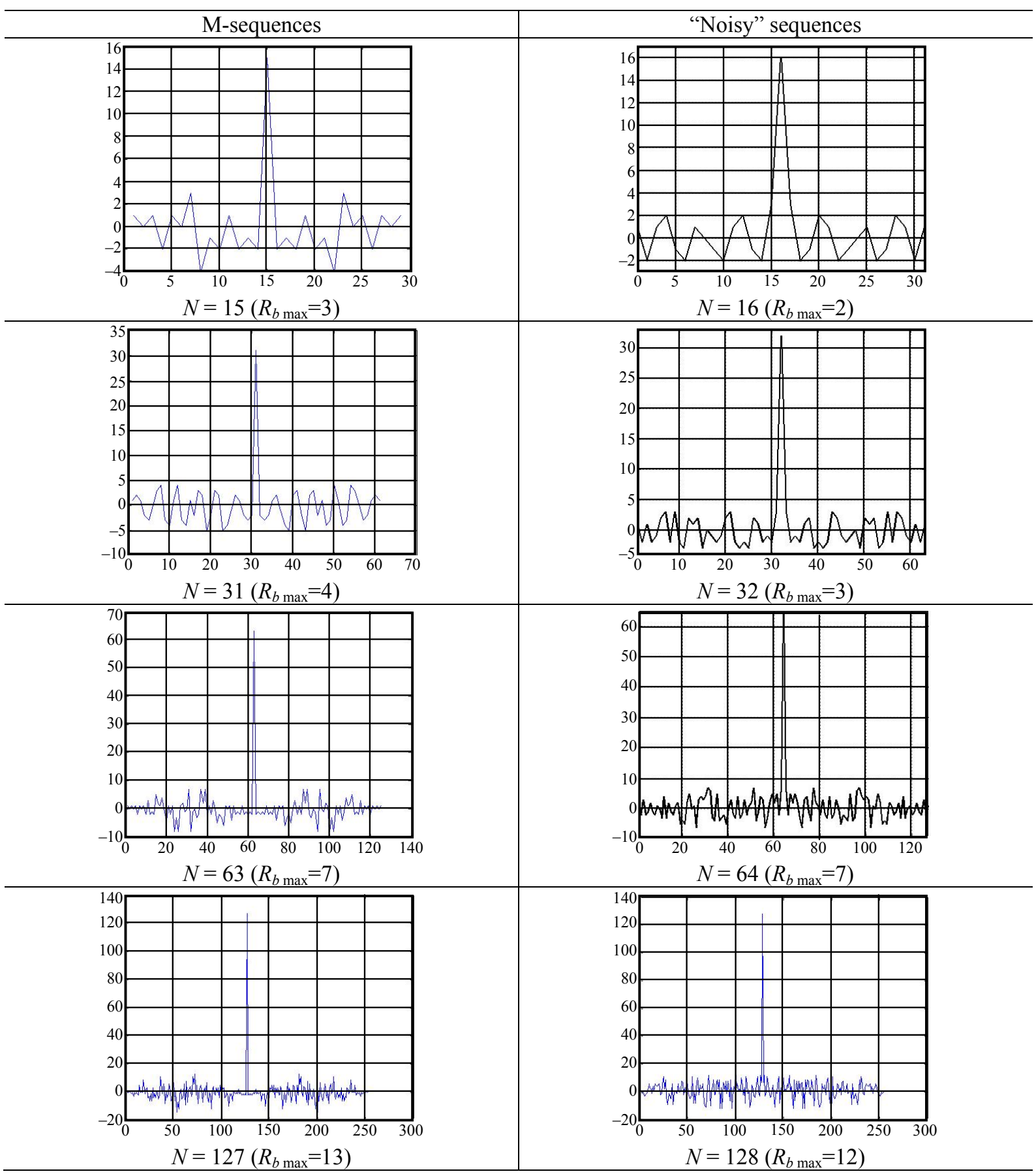


Table 3 exposes examples of binary sequences found using the proposed method for several $N$ values and the assessment of relative computational complexity for exhaustive and "noisy" searching.

Table 3

Sequences found using the proposed method

\begin{tabular}{|c|c|c|c|c|c|}
\hline $\begin{array}{l}\text { Code } \\
\text { length }\end{array}$ & $\begin{array}{c}\text { Example of the obtained binary se- } \\
\text { quence }\end{array}$ & $\begin{array}{l}\text { SLL, } \\
R_{b \max }\end{array}$ & \begin{tabular}{|c|}
$\begin{array}{c}\text { Iterations number } \\
\text { of "noisy" search } \\
V_{n}\end{array}$ \\
\end{tabular} & \begin{tabular}{|c|} 
Iterations num- \\
ber of exhaus- \\
tive search $V$ \\
\end{tabular} & $\begin{array}{l}\text { Relative com- } \\
\text { putational com- } \\
\text { plexity } V / V_{n} \\
\end{array}$ \\
\hline 16 & +--++--+--+-----+ & 2 & 800 & 65535 & 82 \\
\hline 17 & +++-+++---+_-++-+- & 2 & 1100 & 131072 & 119 \\
\hline 50 & $\begin{array}{l}-+--+-+++++---++++---+----++- \\
\quad+++++-+++-+++-+++-++-\end{array}$ & 5 & 225000 & $1,13 \cdot 10^{15}$ & $5,00 \cdot 10^{9}$ \\
\hline 51 & $\begin{array}{c}++-+-++--+--+++------+-+-------+-++- \\
+++----+---++-+\end{array}$ & 5 & 350000 & $2,25 \cdot 10^{15}$ & $6,43 \cdot 10^{9}$ \\
\hline
\end{tabular}

Analysis of data from Table 3 reveals a significant reduction in computational complexity when using the "noisy" search.

Conclusions. The simulation results do evidently demonstrate that the sequence length being up to 128 the maximum levels of the found sequences' ACF sidelobes $R_{b \text { max }}$ are less than at M-sequences case.

Thus, the search algorithm of binary synchronization sequences with desired autocorrelation properties received. According to this algorithm, the sequence can be longer in length and without length limitations. The received sync sequence can be used for frame synchronization in modern digital communication systems that will increase their efficiency and noise immunity.

\section{Література}

1. Мамаев, Н.С. Системы цифрового телевидения и радиовещания / Н.С. Мамаев, Ю.Н. Мамаев, Б.Г. Теряев; под ред. Н.С. Мамаева. - М.: Горячая линия - Телеком, 2006. - 254 с.

2. Smith, D.R. Digital Transmission Systems / D.R. Smith. $-3^{\text {rd }}$ Ed. - Boston: Kluwer Academic Publishers, 2004. - 808 p.

3. Садченко, А.В. Повышение надежности синхронизации систем связи с кодовым разделением каналов / А.В. Садченко, В.А. Аверочкин, О.А. Кушниренко // Труды двенадцатой международной научно-практической конференции «Современные информационные и электронные технологии» (СИЭТ-2011), 23-27 мая, 2011 г., Одесса, Украина. — Одесса: Политехпериодика, 2011. — C. 191.

4. Алгоритм синтеза бинарных синхрокодов произвольной длины с хорошими апериодическими автокорреляционными функциями / А.В.Садченко, В.А. Аверочкин, О.А. Кушниренко, Н.А. Петрусенко // Труды тринадцатой международной научно-практической конференции «Современные информационные и электронные технологии» (СИЭТ-2012), 4-8 июня, 2012 г., Одесса, Украина. - Одесса: Политехпериодика, 2012. - С. 181.

5. Шпинковський, О.А. Символьна синхронізація в системах передачі інформації з амплітуднофазоманіпульованими сигналами / О.А. Шпинковський, А.В. Садченко, М.І. Шпинковська // Пр. Одес. політехн. ун-ту. — 2009. - Вип. 1(31). — С. $102-106$.

\section{References}

1. Mamaev, N.S., Mamaev, Yu.N., \& Teryaev, B.G. (2007). Digital Television and Radio Broadcasting. Moscow: Goryachaya Liniya - Telekom.

2. Smith, D.R. (2004). Digital Transmission Systems (3 ${ }^{\text {rd }}$ Ed.). Boston: Kluwer Academic Publishers.

3. Sadchenko, A.V., Averochkin, V.A., \& Kushnirenko, O.A. (2011). Improving the reliability of synchronization in CDMA communications systems. In Proceedings of $12^{\text {th }}$ International ScientificPractical Conference "Modern Information and Electronic Technologies" (MIET-2011) (p. 191). Odessa: Politehperiodika. 
4. Sadchenko, A.V., Averochkin, V.A., Kushnirenko, O.A., \& Petrusenko, N.A. (2012). The synthesis algorithm of binary synchrocodes of arbitrary length with good aperiodic autocorrelation functions. In Proceedings of $13^{\text {th }}$ International Scientific-Practical Conference "Modern Information and Electronic Technologies" (MIET-2012) (p. 181). Odessa: Politehperiodika.

5. Shpinkovsky, A.A., Sadchenko, A.V., \& Shpinkovskaya, M.I. (2009). Character synchronization in the systems of information transfer with amplitude and phase-manipulated signals. Odes'kyi Politechnichnyi Universytet. Pratsi, 1, 102-106. 